\title{
1 Height-diameter allometry for tropical forest in northern Amazonia
}

2 Robson Borges de Lima ${ }^{1, *}$, Eric Bastos Görgens ${ }^{2}$, Fernando Elias ${ }^{3}$, Jadson Coelho de

3 Abreu $^{1}$, Aldine Luiza Baia ${ }^{4}$, Cinthia Pereira de Oliveira ${ }^{1}$, Diego Armando Silva da Silva ${ }^{5}$,

4 Anderson Pedro Bernardina Batista ${ }^{5}$, Robson Carmo Lima ${ }^{6}$, Eleneide Doff Sotta ${ }^{7}$

51 Laboratório de Manejo Florestal, Universidade do Estado do Amapá, Rua

6 Presidente Vargas, $\mathrm{n}^{\circ}$ 450, Centro, Macapá, Amapá, CEP 68901-262, Brazil;

\section{7 rbl_florestal@yahoo.com.br; cinthia.florestal@gmail.com; Jadson.abreu@ueap.edu.br}

82 Departamento de Engenharia Florestal, Universidade Federal do Vales do

9 Jequitinhonha e Mucuri, Campus JK. Rodovia MGT 367 - Km 583, no 5.000. Alto da

10 Jacuba. Diamantina, Minas Gerais. CEP 39100-000, Brazil; eric.gorgens@ufvjm.edu.br

113 Universidade Federal do Pará, Instituto de Ciências Biológicas, Rede Amazônia

12 Sustentável, Belém, Pará, Brazil; fernandoeliasbio@gmail.com

134 Programa de Pós-graduação em Biodiversidade Tropical-PPGBIO, Universidade

14 Federal do Amapá, Macapá, Brazil; aldine.luiza@gmail.com

155 Instituto Federal de Educação Ciência e Tecnologia do Amapá, Laranjal do Jari,

16 AP - 68.920-000, Brazil; diego.armando@ifap.edu.br; Anderson.batista@ifap.edu.br

176 Programa de Pós-graduação em Biodiversidade e Biotecnologia-Bionorte,

18 Universidade Federal do Amapá, Macapá, Brazil; robsonc191@hotmail.com

197 Empresa Brasileira de Pesquisa Agropecuária, Embrapa, AP - 68900-000,

20 Macapá, Amapá, Brazil. eleneide.sotta@embrapa.br

$21 \quad * \quad$ Correspondence: rbl_florestal@yahoo.com.br; Tel.: (+5596981136789) 


\section{Abstract}

Height measurements are essential to manage and monitor forest biomass and carbon stocks. However, accurate estimation of this variable in tropical ecosystems is still difficult due to species heterogeneity and environmental variability. In this article, we compare and discuss six nonlinear allometric models parameterized at different scales (local, regional and pantropical). We also evaluate the height measurements obtained in the field by the hypsometer when compared with the true tree height. We used a dataset composed of 180 harvested trees in two distinct areas located in the Amapá State. The functional form of the Weibull model was the best local model, showing similar performance to the pantropical model. The inaccuracy detected in the hypsometer estimates reinforces the importance of incorporating new technologies in measuring individual tree heights. Establishing accurate allometric models requires knowledge of ecophysiological and environmental processes that govern vegetation dynamics and tree height growth. It is essential to investigate the influence of different species and ecological gradients on the diameter/height ratio.

Keywords: Hypsometric relationship, non-linear models, forest inventory 


\section{Introduction}

46 The height of the tree at the species and individual level is very relevant information for

47 understanding the autecological characteristics (e.g., fitness, size, ontogenetic stage, trophic position) and essential for monitoring biomass and carbon stocks [1]. Tropical humid forests are formed by a high diversity of species, a complex vertical structure, a dense canopy and high relative humidity. These characteristics make height measurements difficult, inefficient and with a high error [2,3]. As a result, biometrists and forest ecologists tend to measure only the diameter of the trees and estimate the height using allometric models.

Classic logarithmic or polynomial models are often used for non-linear height-diameter relationships [4,5]. Some studies have evaluated the potential of alternative fitted models on a larger scale (continental and pan-tropical) based on the inclusion of environmental variables intrinsic to each region of the tropics [6,7]. Studies using the power-law model $[6,8,9]$ and the Weibull model demonstrate a considerable reduction in errors in height estimates when fitted for local-scale $[1,3,10,11]$. In addition, approaches with monomolecular and hyperbolic models based on diameter growth [12], and including spatial information $[13,14]$, resulted in high precision using a reduced set of predictor variables.

Several efforts have been made to develop height-diameter allometric models for tropical forests at continental scales in Africa [3] and Asia [15]. In South America, we noticed several proposals for models at regional scales $[6,7,16,17]$. However, there are still important gaps related to height-diameter allometric modelling for the different

67 Amazonian humid tropical forest regions. The available field data covers less than 
69 of the Brazilian Amazon is more than $50 \mathrm{~km}$ far away from a forest inventory plot [18-

$70 \quad 20]$.

71 One of the most unknown regions of the Brazilian Amazon is the northeast region of the

72 Amazon (northern Pará and the Amapá States). Such regions demand studies to

73 understand the main implications of using models from the literature. It is essential to

74 provide a better understanding of the variation in biomass and carbon stocks [8,21], as

well as producing responses regarding the transferability of models from one region to

another. The objective of this paper is to develop local height-diameter allometric models

for the tropical humid forest in the northeast of the Brazilian Amazon. We also look to

compare the developed local model to the main pan-tropical and regional models from the literature $[6,16,17]$. Finally, we try to understand the accuracy in estimating the tree height using allometric models, hypsometer and reference height.

\section{Materials and Methods}

\section{Study area}

83 The data were recorded from two sites in the State Forest of Amapá - FLOTA / AP (Fig

1). The first site is located between the municipalities of Calçoene and Oiapoque, ( $2^{\circ} 57^{\prime} 16.00^{\prime \prime} \mathrm{N}$ and $\left.51^{\circ} 27^{\prime} 57.59^{\prime \prime} \mathrm{W}\right)$, accessed via the BR-156 and the Caciporé River, $630 \mathrm{~km}$ from Macapá. The second site is located in the municipality of Porto Grande $87\left(00^{\circ} 34^{\prime} 55,7^{\prime \prime} \mathrm{N}\right.$ and $\left.52^{\circ} 03^{\prime} 54,9^{\prime \prime} \mathrm{W}\right), 130$ km from Macapá. 


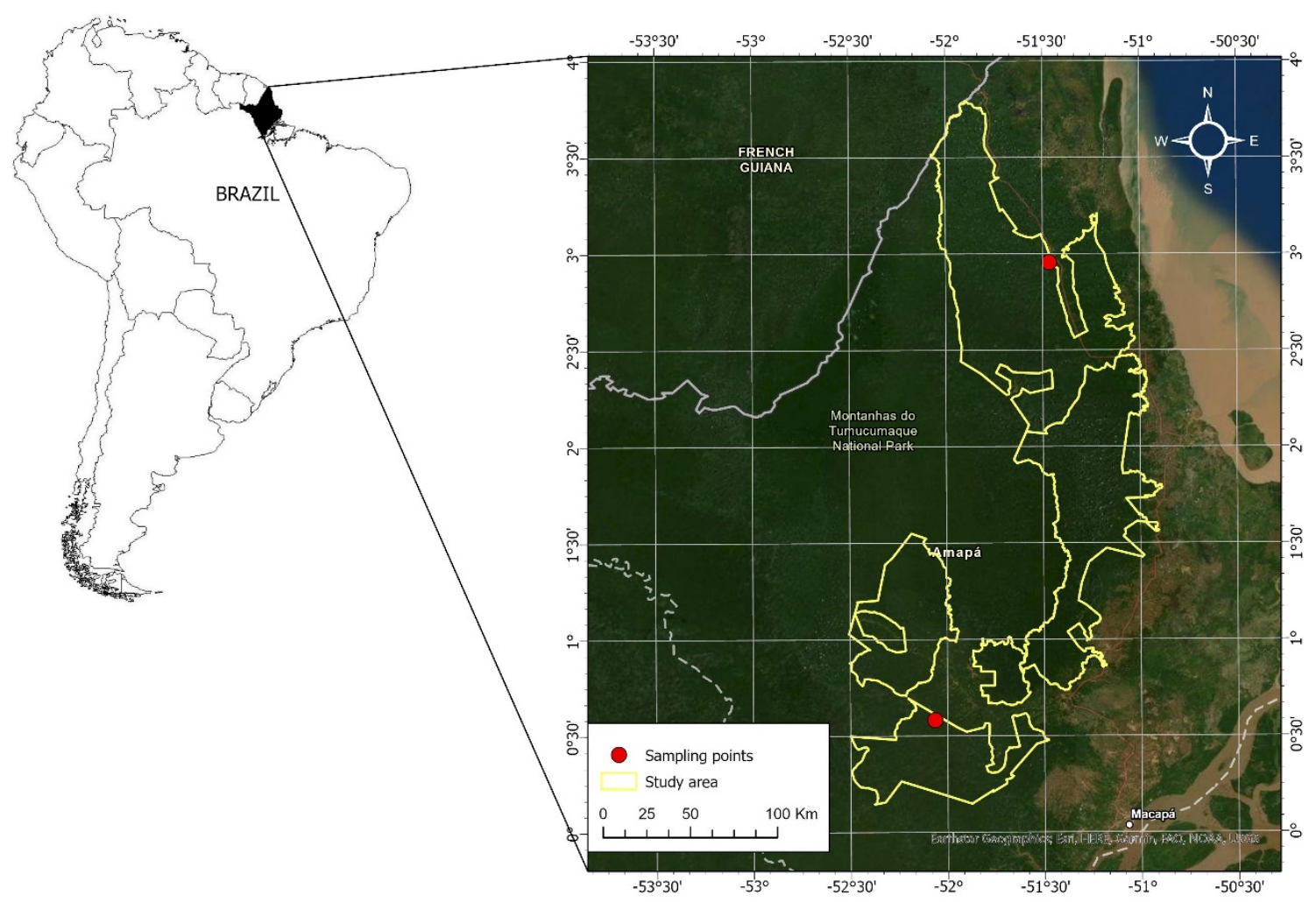

Fig 1. Study locations: area A located in Calçoene and Oiapoque municipalities (A) and area B located in Porto Grande municipality (B).

The climate is classified according to Koppen as Amw (monsoon tropical climate with summer-autumn rains). The rainy season goes from December to June and with a relatively dry period from July to November [22]. The average annual rainfall (last 10 years) is approximately $3,225 \pm 138 \mathrm{~mm}$, with September being the shortest rainy and May showing the highest rainfall. Both sites have low thermal amplitude, varying from $24.8 \pm 0.15^{\circ} \mathrm{C}$ during the coldest month to $26.9 \pm 0.10^{\circ} \mathrm{C}$ during the hottest month [22]

The terrain is formed by numerous drainage channels, where the predominant soil type in both sites is the Dystrophic Red-Yellow Oxisol [23]. Characterized by deep soils, with low fertility and associated with 'terra firme' dense forests (not seasonally flooded). This soil type is a result of the decomposition of Precambrian rocks and, or in special cases, it results from tertiary sediments. Both areas are characterized by the presence of large trees 
such as 'cupiúba' (Goupia glaba Aubl. - Goupiaceae family), 'matamatá' [Eschweilera odora (Poepp. Ex O. Berg) - Lecythidaceae family], 'envira preta' (Guatteria poepiggiana Mart. - Malvaceae family) and 'mandioqueira escamosa' (Qualea spp Vochysiaceae family). Some of these species can reach more than $50 \mathrm{~m}$ in height. The sites also have several species of palm trees and vines [24].

\section{Forest Inventory}

The forest inventory was carried out by launching 100 random plots of $10 \times 10 \mathrm{~m}$ in area A, and 10 systematically arranged plots of $10 \times 10 \mathrm{~m}$ in area B (Fig S1). The systematic plots were arranged in a 'fish bone' pattern, keeping a distance of $50 \mathrm{~m}$ from each other. In area $\mathrm{A}$, all trees with $\mathrm{DBH}$ (diameter at breast height, measured at $1.30 \mathrm{~m}$ from the ground) $\geq 40 \mathrm{~cm}$ were identified and their total biomass and height measurements measured. In total, the 180 trees recorded were distributed in the 82 species and 58 genera. Four plots (from 100) were drawn to quantify the forest biomass inventory of the smaller trees $(5 \leq \mathrm{DBH}<40 \mathrm{~cm})$. Area $\mathrm{B}$ had all trees with $\mathrm{DBH} \geq 5 \mathrm{~cm}$ identified and their total height measurements were obtained with a TruePulse hypsometer (Vertex 360). DBH was always measured above the formation of the buttress root. All trees were felled to measure the total green biomass above the ground and the true total height $(\mathrm{Ht})$.

\section{Allometric models}

Six nonlinear models commonly used to describe the height-diameter relationship were tested (Table 1) $[3,5,6,9,17]$. Due to the low density of recorded trees per species and the absence of evident ecological gradients within the dataset, the models were fitted disregarding the species. The data set was randomly divided into two subsets: $70 \%$ (126 
for calibration ranged from 5.12 to $159.15 \mathrm{~cm}$, and height ranged from $5.0 \mathrm{~m}$ to $51.0 \mathrm{~m}$.

The DBH in the validation set varied between 40.9 and $159 \mathrm{~cm}$ and the height between

Table 1. Hypsometric models used to describe the relationship between total height and diameter of the trees. $a$ and $b$ are the parameters to be estimated; DBH is diameter at breast height measured at $1.30 \mathrm{~m}$ from ground level in centimeters $(\mathrm{cm})$; the highest total height of the sample, Ht is the total height of each tree in meters; $\varepsilon$

is a random error; and $L n$ is the logarithm at the Neperian base (2.7128).

\begin{tabular}{|l|c|}
\hline \multicolumn{1}{|c|}{ Model } & Functional form \\
\hline 1. Ln & $H t=a+b \times \operatorname{Ln}(D B H)$ \\
\hline 2. Log-log & $H t=\exp (a+b \times \operatorname{Ln}(D B H))$ \\
\hline 3. Weibull & $H t=\max (H t) \times\left(1-\exp \left(-a \times D B H^{b}\right)\right)$ \\
\hline 4. Weibull 2 & $H t=H m \times\left(1-\exp \left(-a \times D B H^{b}\right)\right)$ \\
\hline 5. Rectangular - Hyperbolic & $H t=((\max (H t) \times D A P) /(a+D B H))-b$ \\
\hline 6. Rectangular - Hyperbolic 2 & $H t=((H m \times D B H) /(a+D B H))-b$ \\
\hline
\end{tabular}

We used the nlme package [25] in software $\mathrm{R}$ version 4.0.2 [26] to estimate the model parameters. The fitting was evaluated by the coefficient of determination $\left(\mathrm{R}^{2}\right)$, root mean square error (RMSE), bias, maximum likelihood (AIC) and differences in AIC $(\Delta i)$ [27]. The $\Delta i$ was used to classify the models considering the empirical support proposed by [27]: $\Delta i \leq 2$ has substantial support, $2<\Delta i \leq 10$ has marginal support and $\Delta i>10$ has no support at all. For more details, see supplementary information (methods). The graphic analysis for the percentage residues was also carried out as a function of the estimated 
145 values of the height to identify models with homogeneous variance. Finally, the models

146 were analyzed including the confidence limits $(p<0.05)$ and regressing observed and

147 estimated height compared to a linear trend of $1: 1$.

148 For the validation data $(30 \%=54$ trees $)$, in addition to the best local model, the individual

149 height was estimated considering the regional equation proposed by [16], continental

150 equation proposed by [6], and pantropical equation proposed by [17]. In addition, the

151 estimated heights were also compared with the hypsometer measurements to analyze the accuracy and the error associated with the field measurements. The pantropical equation was based on the Weibull model, while the Continental equation for South America was based on the exponential form, and the regional equation was built based on log-log form for Santarém and Manaus data (see Table 2).

Table 2. Regional, continental and pan-tropical allometric equations tested to

\begin{tabular}{|l|c|l|}
\hline \multicolumn{1}{|c|}{ Model } & Funcional fit & Autor \\
\hline 1. Log-log & $\mathrm{Ht}=0.44+0.64 \times \mathrm{Ln}(\mathrm{DBH})$ & {$[16]-$ Manaus } \\
\hline 2. Log-log & $\mathrm{Ht}=0.53+0.53 \times \operatorname{Ln}(\mathrm{DBH})$ & {$[16]-$ Santarém } \\
\hline 3. Weibull & $\mathrm{Ht}=\max (\mathrm{Ht}) \times\left(1-\exp \left(-0.5320 \times \mathrm{DBH}^{0.5296}\right)\right)+0.007$ & {$[17]$} \\
\hline 4. Exponential & $\mathrm{Ht}=35.83-31.15 \times \exp (-0.029 \times \mathrm{DBH})$ & {$[6]$} \\
\hline
\end{tabular}

The performance of the models was evaluated comparing to real heights by the standard error (RSE) and the coefficient of variation $(\mathrm{CV}, \mathrm{p} \geq 0.05)$ : 
165 Where: $\mathrm{Ht}_{\mathrm{ALTi}}$ and $\mathrm{Ht}_{\mathrm{MESi}}$ are the estimated and observed height for tree $\mathrm{i}$, respectively.

166 The null hypothesis $\left(\mathrm{H}_{0}\right)$ was that the heights estimated by one of the models or by

167 hypsometer do not differ from the true height. When a significant effect was identified,

168 the Tukey test $(\mathrm{p}<0.05)$ was used to discriminate the differences between the groups.

169 All analyzes were performed with Software R® version 4.0.2 (R Core Team 2020), using

170 the agricolae package [28].

\section{Results}

\section{Local allometric modeling}

173 All the adjusted models had a determination coefficient greater than $84 \%$, and the difference between the AIC values of the best and worst model was less than 10 units (Table 3). The model parameters were significant at a 95\% significance level $(\mathrm{p}<0.05)$. The adjusted models showed good adjustments, producing satisfactory estimates

177 concerning the trend of the observed data and valid confidence intervals $(\mathrm{p}<0.05)($ Fig 178 2).

Table 3. Estimated parameters and model selection statistics for equations that describe the hypsometric relationship. The values in bold show the model better. $\mathbf{R}^{2}$ is the correlation coefficient, AIC is the Akaike Information Criterion, $\Delta \mathrm{i}$ is the difference in AIC between each model and the best-fit model, wi is the Akaike weight, RMSE is the square root of the average error and the Bias is the systematic deviation of models.

\begin{tabular}{|c|c|c|c|c|c|c|c|c|c|c|}
\hline \multirow{2}{*}{ Model } & \multicolumn{4}{|c|}{ Parameters } & \multicolumn{5}{c|}{ Performance fits } & \multirow{2}{*}{ IC $(<.05)$} \\
\cline { 2 - 12 } & $\mathrm{a}$ & $\mathrm{b}$ & $\mathrm{c}$ & $\mathrm{R}^{2}$ & AIC & $\Delta_{i}$ & $w i$ & RMSE & Bias & \\
\hline Ln & -10.0314 & 10.3848 & & 0.840 & 926.15 & 7.24 & 0.027 & 4.369 & 0.049 & {$[16.67 ; 24.96]$} \\
\hline
\end{tabular}




\begin{tabular}{|c|c|c|c|c|c|c|c|c|c|c|}
\hline $\ln -\ln$ & 1.5025 & 0.4808 & & 0.844 & 921.59 & 2.68 & 0.262 & 4.307 & 0.076 & {$[16.77 ; 24.99]$} \\
\hline Rec & 46.5487 & -4.1623 & & 0.845 & 920.37 & 1.46 & 0.482 & 4.291 & 0.062 & {$[16.71 ; 24.92]$} \\
\hline Rec2 & 53.3355 & -4.6631 & 53.4504 & 0.846 & 922.04 & 3.13 & 0.209 & 4.286 & 0.061 & {$[16.70 ; 24.92]$} \\
\hline Weibull & $\mathbf{0 . 0 6 2}$ & $\mathbf{0 . 6 8 6 7}$ & & $\mathbf{0 . 8 4 7}$ & $\mathbf{9 1 8 . 9 1}$ & $\mathbf{0}$ & $\mathbf{1}$ & $\mathbf{4 . 2 5 1}$ & $\mathbf{0 . 0 5 8}$ & {$[16.70 ; 24.98]$} \\
\hline Weibull2 & 0.0554 & 0.6215 & $\mathbf{6 4 . 5 6 1 5}$ & 0.848 & 919.74 & 0.83 & 0.66 & 4.275 & 0.063 & {$[16.74 ; 24.93]$} \\
\hline
\end{tabular}
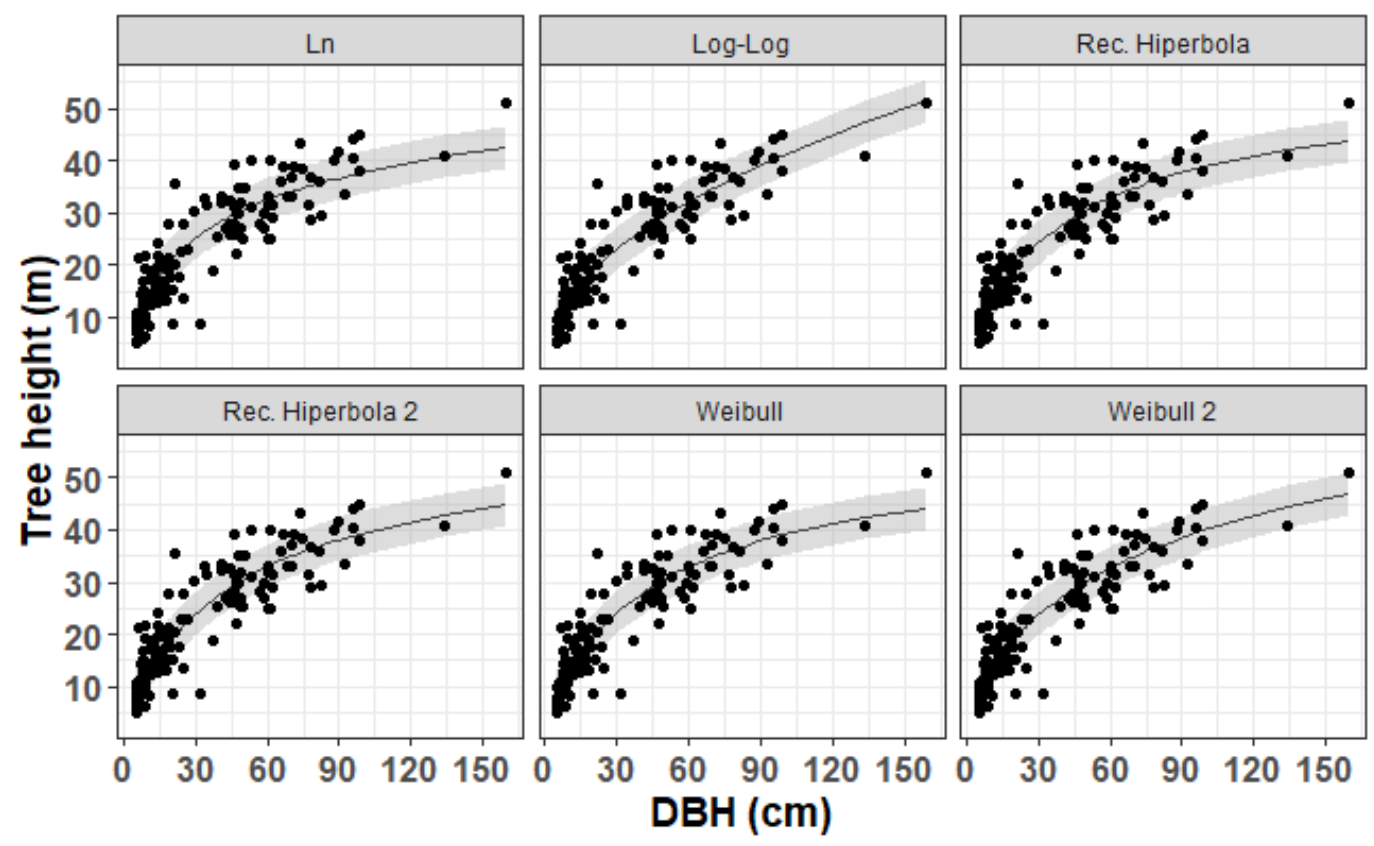

186

187

Fig 2. Estimates and prediction errors of local models adjusted for total height data in tropical forest in Amapá.

The best local model was the Weibull which showed higher accuracy, smaller error measures, smaller systematic deviation and higher support, with $\mathrm{AIC}=918.910, \mathrm{R}^{2}=$ $0.84, \operatorname{RMSE}=4.251$, Bias $=0.058, \mathrm{wi}=1.0$ and $\Delta \mathrm{i}=0($ Table 3 and Fig S2 $)$. The Weibull model 2 differed from Weibull mainly due to the asymptotic height. The visualization of the standardized residues according to the predicted height showed an absence of

194 heteroscedasticity (Fig 3), concentrating the distribution and higher density of errors between -25 and $25 \%$, which corroborates the fitting parameters (Table 3 ). 


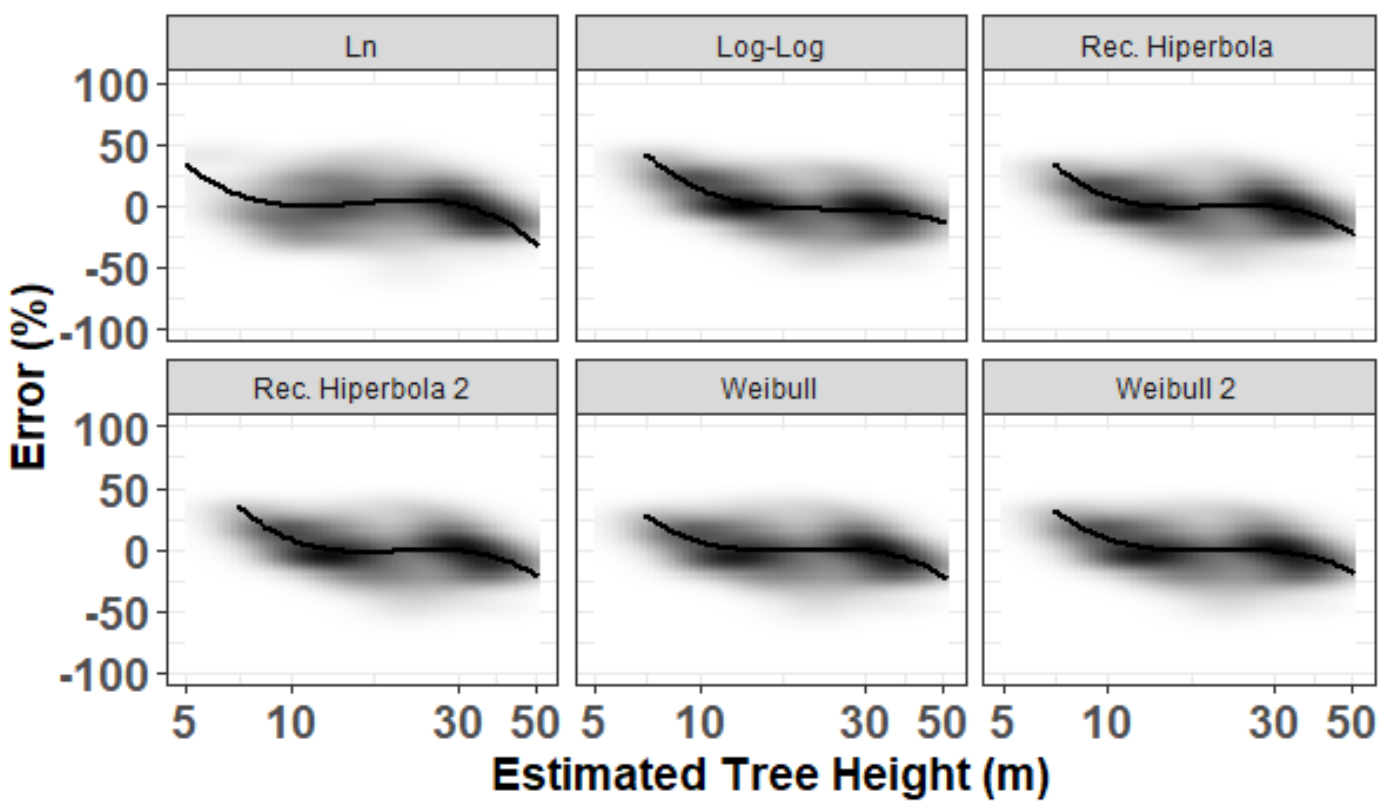

Fig 3. Percentage error (estimated Ht minus observed Ht, divided by the observed Ht, in \%) vs estimated height values for the six non-linear theoretical models; the thick black line represents a spline regression of the data points, illustrating a slight negative bias at large estimated height values (values $>30 \mathrm{~m}$ ). The background represents the density of the data point $(n=126$ trees $)$.

\section{Local, regional, continental and pantropical allometric models}

The model comparison (best local adjusted, regional, continental and pantropical obtained from the literature) produced different trends, most of them differing at the total asymptotes. The validation dataset indicates that our local model adjusted in this study and the pantropical-Weibull model by [17] have similar precision and performance when predicting the tree heights. The continental model proposed by [6] and the regional models proposed by [16] underestimate height values when compared to the validation data (Fig 4). For those models, the relative error increased while height values also increased (Fig S3). The height estimated by the hypsometer showed large variation when compared to the validation dataset, but showed a consistent tendency to underestimate. 

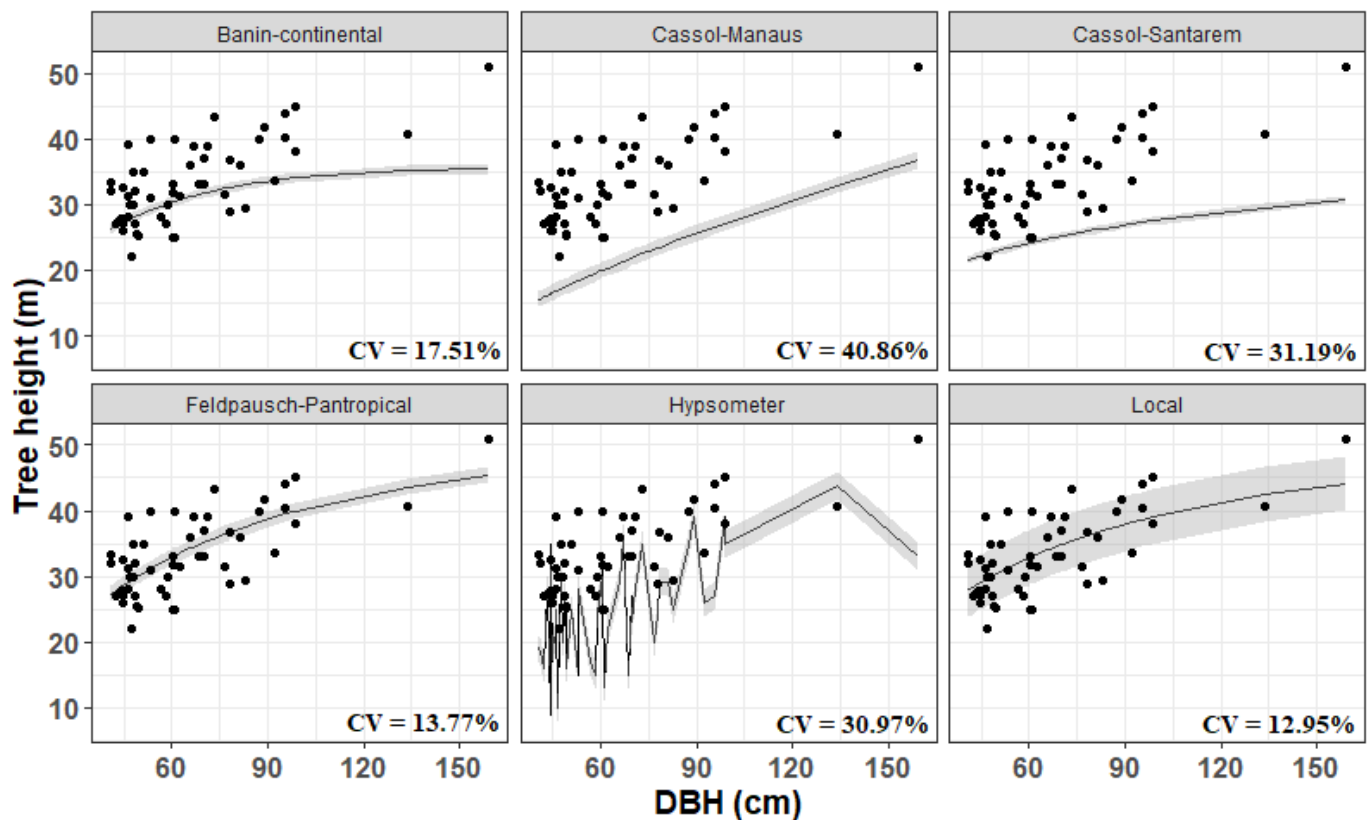

213 Fig 4. Estimates and percentage errors of allometric models (local, regional, continental and pantropical) and hypsometer for prediction of total height in tropical rainforest in Amapá.

The CV\% practically doubles for regional-scale models and keeps stable for the

217 continental and pantropical-scale models. The highest mean CV (40.86\%) was noticed

218 for the regional model proposed by [16] (Manaus regional model). The lowest mean bias

219 was related to the local model $( \pm 4.29 \mathrm{~m})$, followed by the pan-tropical model by [17] ( \pm

$2204.57 \mathrm{~m}$ ), both based on Weibull form. The local and pantropical models accurately

221 estimated the average height $(\mathrm{CV}<14 \%)$, showing low average forecasting errors $(<$

222 20\%) even for the tallest trees (see Fig A3). Based on the statistical test, we can notice

223 the superior performance of the local and pantropical models (Fstat $=60.92 \mathrm{p}<.001$, df $224=364, \mathrm{CV}=16.86 \%)($ Fig 5, and also see table S2). 


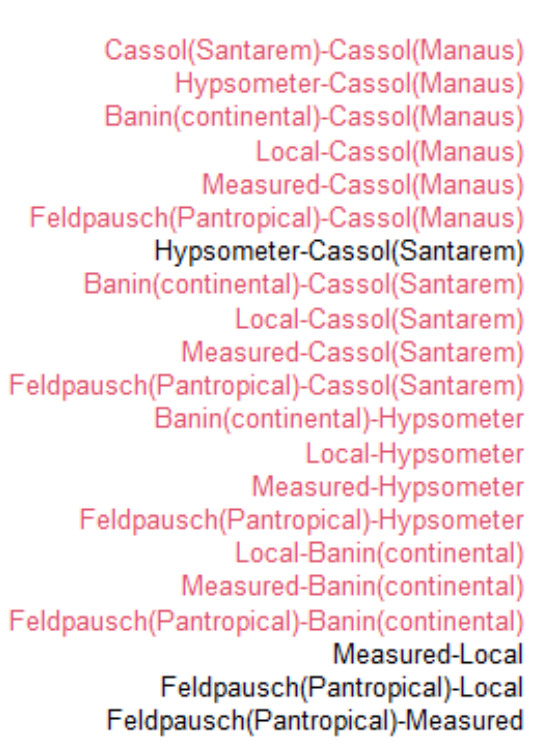

Feldpausch(Pantropical)-Local
Feldpausch(Pantropical)-Measured

The red contrasts indicate a statistical difference of zero by the Tukey test $(p<0.05)$.

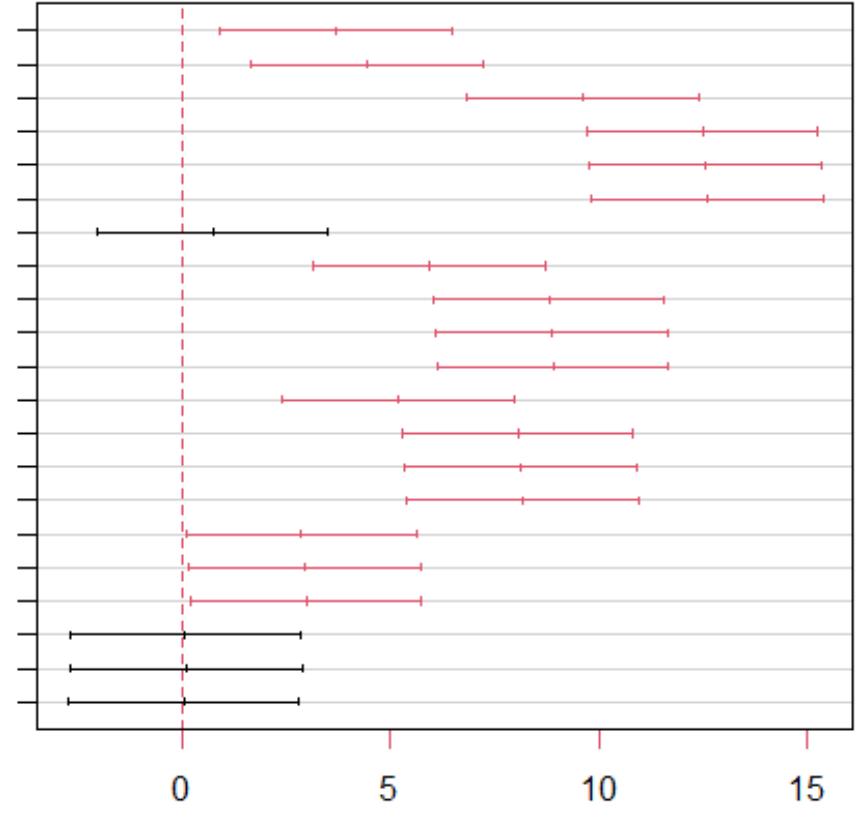

15

230 The tree height obtained by the hypsometer showed a systematic underestimation

231 between diameter classes, when compared to the height recorded from the felled trees.

232 We also noticed a larger amplitude for the tree height compared to observed range (Fig $6)$. 


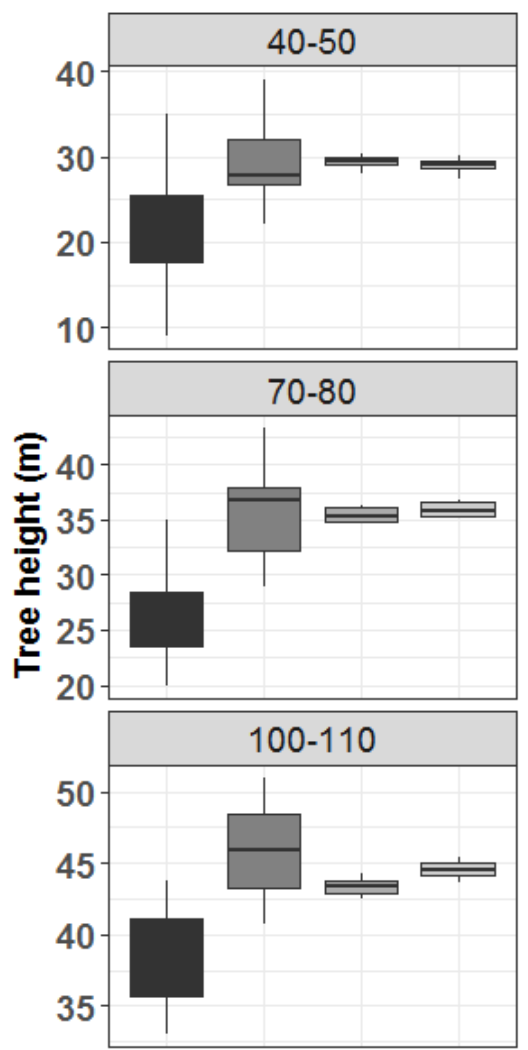

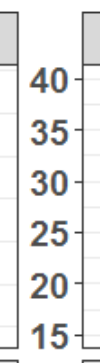
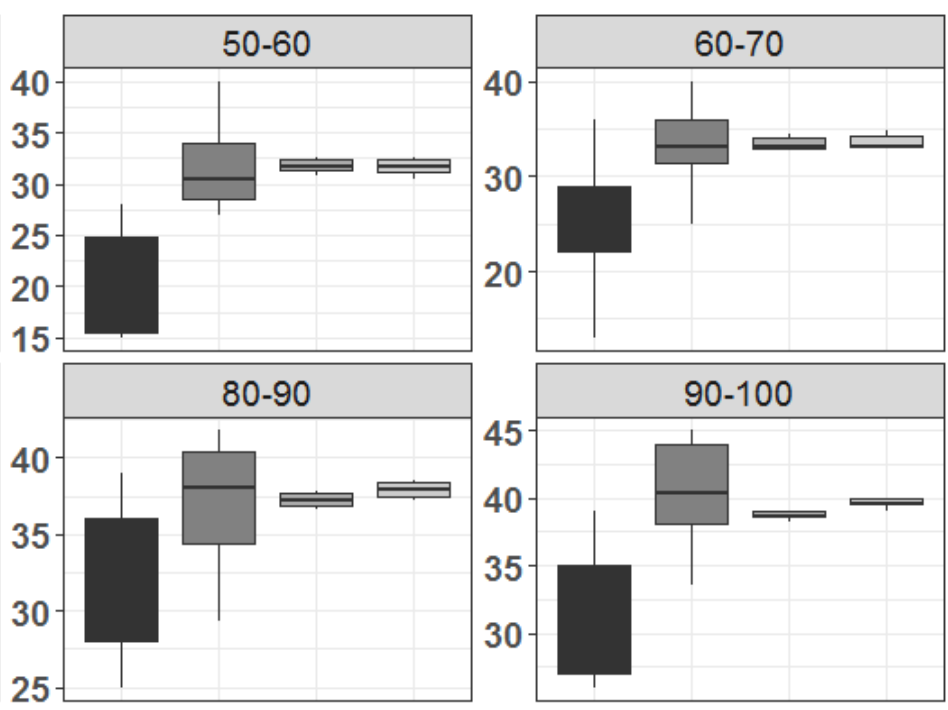

Fig 6. Comparison of height measurements by diameter class between the values generated by the hypsometer - Hypsometer, total length of the felled tree stem Measured, height generated by the best local model - Weibull local height and height generated by the pan-tropical model - Weibull [17].

\section{Discussion}

Tree height is essential to understand the dynamics of forest ecosystems, incorporating ecological characteristics of the species constituting the canopy. For example, the height can help to explain some of the carbon storage variations and productivity in ecosystem types [1]. Our results revealed a significant difference in the height recorded by the hypsometer when compared to the real height of felled trees. The errors produced by the hypsometer introduced large variation in heights in different diameter classes (see fig 6), 
247 indicating that the accuracy of this method depends on a strong trigonometric calibration

248 and training [29]. On the other hand, it is necessary to assess the variability of these errors

249 and possible trends in their occurrence, as well as to train field teams with the most up-

250 to-date equipment and technological resources [2].

251 The tree height-diameter relationship depends on a series of physiological, biogeographic and environmental factors [7,30,31]. Besides climatic conditions and altitude [7,32,33] local edaphic factors, evolutionary and architectural restrictions [34,35], and the competition for space [36] could also influence the height-diameter relationship. [33] showed that in stressed environments by temperature and/or water the tree height is typically much lower than expected in a purely mechanical model.

In uneven forests, the great height variability within a diametric class may result in relative instability, resulting in measurement errors [37]. Local height-diameter allometric relationships implicitly incorporate geography and environment variation $[7,17]$. The allometric equation proposed in this work implements a local approach targeting the tropical rainforest from Northeast Amazonia (Amapá State). Which is characterized by the high heights variance and species heterogeneity, suggesting that a local approach should be recommended.

Most of the variation present in the height variable was explained by the local Weibull model $(\sim 84 \%)$. The Weibull functional form is ecologically consistent and represents biological realism in dense forests $[5,21]$. The maximum height of the trees reaches a plateau through competition for light and nutrients [36] controlling the non-linear growth curve [5]. The correlation between diameter and height generates a form factor (trunk taper coefficient) that explains a good part of this behavior $(\mathrm{r}=91 \%)$. The trunk shape variation also explains the growth in height, together with the size and shape of the crown 
272 Our results showed that the continental allometric models proposed by [6] and the

273 regional model proposed by [16] are not suitable for dense forests in Amapá. Site

274 properties may be affecting the tree height, resulting in interspecific and intraspecific

275 variation $[40,41]$. We can find several examples in the literature about models that do not

276 produce accurate estimates for some specific regions. For example, the pantropical

277 height-diameter model by [17] did not produce accurate estimates of tree height in Asia

278 [15]. In another study, regional models proposed for Central Africa [6,17] overestimated

279 the tree heights for central Congo if compared to the pan-tropical model proposed by [7]

$280[3,10]$.

281 Both regional models analyzed in our study showed a much higher average bias (+ $28231.19 \%$, and $40.86 \%$, respectively Santarém and Manaus) when compared to the local model $(+12.95 \%)$. A possible cause for the low performance is the low representativeness of the existent variations. Local allometric equations must consider the environmental gradients and species diversity to properly represent the variation presented in the vegetation [41]. This is exactly the limitation of the regional model, since they may not capture the existent heterogeneity observed for different scales [7,17]. [1] show that height-diameter models derived locally can be parameterized from 40 height observations. When the sampling is too small, the models may perform poorly in height prediction. The main reasons are: (i) non-linear relationships, such as asymptotic maximum heights, may not be evident in smaller sets of calibration data [42] and (ii) models can be excessively influenced by outliers (trees that are unusually tall or short for their diameter). [17] developed a set of regional-specific height-diameter allometries to 
In general, the deviations observed between models are associated with environmental

reach their potential in height [31]. The pantropical model presented accurate height

\section{Conclusions}

The local model proposed in this work performed similarly to the pantropical model by

[17]. Establishing accurate height estimates requires a solid initial understanding of allometric models that explain or address the ecophysiological and environmental processes that govern vegetation dynamics and tree height growth. We suggest that future studies analyze the influence of different species and ecological gradients on the diameter/height ratio. The low performance of the hypsometer in height estimates reinforces the importance of incorporating new technologies in the process of measuring the attributes of individual trees such as LiDAR terrestrial or LiDAR aerial.

Supporting information: Appendix A: Supplementary information for statistical analysis of nonlinear models adjusted to estimate total height in tropical rainforest in Amapá. Fig A1. Distribution of fixed sampling units of $10 \times 10 \mathrm{~m}$ to carry out the forest inventory in Area B. Adapted from Oliveira et al. (2012). Appendix B: Supplementary information for the statistical results of adjustment and selection of non-linear models for total height estimation in tropical rainforest in Amapá. Fig A2. Predicted vs. scatter plot 
observed height $(\mathrm{m})$ by the best local model (Weibull). The solid blue line represents the estimated values with gray confidence bands $(p<0.05)$. Red dashed lines represent predictions for height values. The solid black line represents the 1:1 ratio; Fig A3. Percent error (validation estimate minus observed $\mathrm{Ht}$, divided by observed $\mathrm{Ht}$, in \%) vs estimated height values for the six height prediction alternatives; the thick black line represents a spline regression of the data points. The background represents the density of the data point $(\mathrm{n}=54$ trees); Table A1 - Comparison of mean height differences generated by local, regional, continental, pan-tropical and hypsometer model estimates with the true mean height measured in the field after tree thinning. Means followed by the same letters did not differ significantly by the Tukey test $(\mathrm{p}<0.05)$.

Author Contributions: Conceptualization, R.L. and E.G.; methodology, R.L., E.G.,

A.L.B.; R.C.L., E.S.; software, R.L. and E.G.; validation, R.L. and E.G.; formal analysis, R.L., E.G., F.E., J. A., C.O., A.L.B., D.S., A.P.B.; investigation, , R.L., E.G., F.E., J. A., C.O., A.L.B., D.S., A.P.B. and R.C.L., E.S.; resources, , R.L., E.G., R.C.L.; data curation, R.L. and R.C.L. writing — original draft preparation, R.L., E.G., F.E., J. A., C.O., A.L.B., D.S., A.P.B.; writing - review and editing, R.L., E.G. and F.E.; visualization, R.L. and E.G.; supervision, R.L. and E.G.; project administration, R.L. and R.C.L., E.S.; funding acquisition, R.L., E.G., R.C.L., E.S. All authors have read and agreed to the published version of the manuscript.

Funding: Funding was provided by the Coordenação de Aperfeiçoamento de Pessoal de Desenvolvimento Científico e Tecnológico (Processes 403297/2016-8 and 301661/2019-

7) and (Processes 550467/2010-6)

Data Availability Statement: Data can be made available upon request to authors. 
Acknowledgments: We thanks Universidade Federal dos Vales do Jequitinhonha e

Mucuri (UFVJM) for support this work. We also thank the Universidade do Estado do

Amapá (UEAP) for financial support to defray any fees for future publications of this

manuscript.

Conflicts of Interest: The authors declare no conflict of interest.

\section{References}

1. Sullivan MJP, Lewis SL, Hubau W, Qie L, Baker TR, Banin LF, et al. Field methods for sampling tree height for tropical forest biomass estimation. Methods Ecol Evol.

2. Larjavaara M, Muller-Landau HC. Measuring tree height: a quantitative comparison of two common field methods in a moist tropical forest. Metcalf J, editor. Methods Ecol Evol. 2013;4: 793-801. doi:10.1111/2041-210X.12071

3. Mensah S, Pienaar OL, Kunneke A, du Toit B, Seydack A, Uhl E, et al. Height Diameter allometry in South Africa's indigenous high forests: Assessing generic models performance and function forms. Forest Ecology and Management. 2018;410: 1-11. doi:10.1016/j.foreco.2017.12.030

4. Gómez-García E, Diéguez-Aranda U, Castedo-Dorado F, Crecente-Campo F. A Comparison of Model Forms for the Development of Height-Diameter Relationships in Even-Aged Stands. Forest Science. 2014;60: 560-568. doi:10.5849/forsci.12-099

5. Mehtätalo L, de-Miguel S, Gregoire TG. Modeling height-diameter curves for prediction. Can J For Res. 2015;45: 826-837. doi:10.1139/cjfr-2015-0054

6. Banin L, Feldpausch TR, Phillips OL, Baker TR, Lloyd J, Affum-Baffoe K, et al. What controls tropical forest architecture? Testing environmental, structural and floristic drivers: Determinants of tropical forest architecture. Global Ecology and Biogeography. 2012;21: 1179-1190. doi:10.1111/j.1466-8238.2012.00778.x

7. Chave J, Réjou-Méchain M, Búrquez A, Chidumayo E, Colgan MS, Delitti WBC, et al. Improved allometric models to estimate the aboveground biomass of tropical trees. Glob Change Biol. 2014;20: 3177-3190. doi:10.1111/gcb.12629

8. Imani G, Boyemba F, Lewis S, Nabahungu NL, Calders K, Zapfack L, et al. Heightdiameter allometry and above ground biomass in tropical montane forests: Insights from the Albertine Rift in Africa. Hui D, editor. PLoS ONE. 2017;12: e0179653. doi:10.1371/journal.pone.0179653 
9. Mensah S, Veldtman R, Seifert T. Allometric models for height and aboveground biomass of dominant tree species in South African Mistbelt forests. Southern Forests: a Journal of Forest Science. 2017;79: 19-30. doi:10.2989/20702620.2016.1225187

10. Kearsley E, Moonen PC, Hufkens K, Doetterl S, Lisingo J, Boyemba Bosela F, et al. Model performance of tree height-diameter relationships in the central Congo Basin. Annals of Forest Science. 2017;74: 7. doi:10.1007/s13595-016-0611-0

11. Ledo A, Cornulier T, Illian JB, Iida Y, Kassim AR, Burslem DFRP. Re-evaluation of individual diameter : height allometric models to improve biomass estimation of tropical trees. Ecol Appl. 2016;26: 2376-2382. doi:10.1002/eap.1450

12. Oyamakin SO, Chukwu AU. On Hyperbolic Monomolecular growth model in Height/Diameter growth of PINES. Journal of Applied Mathematics, Statistics and Informatics. 2015;11: 5-17. doi:10.1515/jamsi-2015-0001

13. Meng Q, Cieszewski CJ, Strub MR, Borders BE. Spatial regression modeling of tree height-diameter relationships. Can J For Res. 2009;39: 2283-2293. doi:10.1139/X09-136

14. Schmidt M, Kiviste A, von Gadow K. A spatially explicit height-diameter model for Scots pine in Estonia. Eur J Forest Res. 2011;130: 303-315. doi:10.1007/s10342-010-0434-8

15. Rutishauser E, Noor'an F, Laumonier Y, Halperin J, Rufi'ie, Hergoualc'h K, et al. Generic allometric models including height best estimate forest biomass and carbon stocks in Indonesia. Forest Ecology and Management. 2013;307: 219-225. doi:10.1016/j.foreco.2013.07.013

16. Cassol HLG, Shimabukuro YE, Carreiras JM de B, Moraes EC. Improved tree height estimation of secondary forests in the Brazilian Amazon. Acta Amaz. 2018;48: 179-190. doi:10.1590/1809-4392201700844

17. Feldpausch TR, Banin L, Phillips OL, Baker TR, Lewis SL, Quesada CA, et al. Height-diameter allometry of tropical forest trees. Biogeosciences. 2011;8: 10811106. doi:10.5194/bg-8-1081-2011

18. Tejada G, Görgens EB, Ovando A, Ometto JP. Mapping data gaps to estimate biomass across Brazilian Amazon forests. For Ecosyst. 2020;7: 25. doi:10.1186/s40663-020-00228-1

19. Stropp J, Umbelino B, Correia R, Campos-Silva J, Ladle R, Malhado A. The ghosts of forests past and future: deforestation and botanical sampling in the Brazilian Amazon. Ecography. 2020;43. doi:10.1111/ecog.05026

20. Marvin DC, Asner GP, Knapp DE, Anderson CB, Martin RE, Sinca F, et al. Amazonian landscapes and the bias in field studies of forest structure and biomass. Proc Natl Acad Sci USA. 2014;111: E5224-E5232. doi:10.1073/pnas.1412999111 
21. Feldpausch TR, Lloyd J, Lewis SL, Brienen RJW, Gloor M, Monteagudo Mendoza A, et al. Tree height integrated into pantropical forest biomass estimates. Biogeosciences. 2012;9: 3381-3403. doi:10.5194/bg-9-3381-2012

22. Alvares CA, Stape JL, Sentelhas PC, de Moraes Gonçalves JL, Sparovek G. Köppen's climate classification map for Brazil. metz. 2013;22: 711-728. doi:10.1127/0941-2948/2013/0507

23. Santos HG dos, Jacomine PKT, Anjos LHC dos, Oliveira VA de, Lumbreras JF, Coelho MR, et al. Brazilian Soil Classification System. Brasília, DF: Embrapa, 2018.; 2018.

Available: http://www.infoteca.cnptia.embrapa.br/handle/doc/1094001

24. de Lima RB, Rutishauser E, da Silva JAA, Guedes MC, Herault B, de Oliveira CP, et al. Accurate Estimation of Commercial Volume in Tropical Forests. Forest Science. 2021;67: 14-21. doi:10.1093/forsci/fxaa032

25. Pinheiro J, Bates D, DebRoy SS, Sarkar D. Nlme: Linear and Nonlinear Mixed Effects Models. R package version 31-110. 2013;3: 1-113.

26. R: The R Project for Statistical Computing. [cited 17 Jun 2021]. Available: https://www.r-project.org/

27. Burnham KP, Anderson DR, Burnham KP. Model selection and multimodel inference: a practical information-theoretic approach. 2nd ed. New York: Springer; 2002.

28. Mendiburu F de. agricolae: Statistical Procedures for Agricultural Research. 2021. Available: https://CRAN.R-project.org/package=agricolae

29. Skovsgaard JP. MENSURATION | Forest Measurements. In: Burley J, editor. Encyclopedia of Forest Sciences. Oxford: Elsevier; 2004. pp. 550-566. doi:10.1016/B0-12-145160-7/00142-3

30. Chave J, Andalo C, Brown S, Cairns MA, Chambers JQ, Eamus D, et al. Tree allometry and improved estimation of carbon stocks and balance in tropical forests. Oecologia. 2005;145: 87-99. doi:10.1007/s00442-005-0100-x

31. Gorgens EB, Nunes MH, Jackson T, Coomes D, Keller M, Reis CR, et al. Resource availability and disturbance shape maximum tree height across the Amazon. Glob Change Biol. 2021;27: 177-189. doi:10.1111/gcb.15423

32. Jackson TD, Shenkin AF, Majalap N, Bin Jami J, Bin Sailim A, Reynolds G, et al. The mechanical stability of the world's tallest broadleaf trees. Biotropica. 2021;53: 110-120. doi:10.1111/btp.12850

33. Lines ER, Zavala MA, Purves DW, Coomes DA. Predictable changes in aboveground allometry of trees along gradients of temperature, aridity and competition: Predictable variation in tree aboveground allometry. Global Ecology and Biogeography. 2012;21: 1017-1028. doi:10.1111/j.1466-8238.2011.00746.x 
34. Goodman RC, Phillips OL, Baker TR. The importance of crown dimensions to improve tropical tree biomass estimates. Ecological Applications. 2014;24: 680698. doi:10.1890/13-0070.1

35. Kempes CP, West GB, Crowell K, Girvan M. Predicting Maximum Tree Heights and Other Traits from Allometric Scaling and Resource Limitations. Evans DM, editor. PLoS ONE. 2011;6: e20551. doi:10.1371/journal.pone.0020551

36. Iida Y, Kohyama TS, Kubo T, Kassim AR, Poorter L, Sterck F, et al. Tree architecture and life-history strategies across 200 co-occurring tropical tree species: Tree architecture and life-history strategies across 200 species. Functional Ecology. 2011;25: 1260-1268. doi:10.1111/j.1365-2435.2011.01884.x

37. Sharma M. Comparing Height-Diameter Relationships of Boreal Tree Species Grown in Plantations and Natural Stands. Forest Science. 2016;62: 70-77. doi:10.5849/forsci.14-232

38. Collet C, Lanter O, Pardos M. Effects of canopy opening on height and diameter growth in naturally regenerated beech seedlings. Ann For Sci. 2001;58: 127-134. doi:10.1051/forest:2001112

39. Kellner JR, Clark DB, Hubbell SP. Pervasive canopy dynamics produce short-term stability in a tropical rain forest landscape. Ecology Letters. 2009;12: 155-164. doi:10.1111/j.1461-0248.2008.01274.x

40. Siefert A, Violle $\mathrm{C}$, Chalmandrier L, Albert CH, Taudiere A, Fajardo A, et al. A global meta-analysis of the relative extent of intraspecific trait variation in plant communities. Ecology Letters. 2015;18: 1406-1419. doi:10.1111/ele.12508

41. Siliprandi NC, Nogueira EM, Toledo JJ, Fearnside PM, Nascimento HEM. Intersite variation in allometry and wood density of Goupia glabra Aubl. in Amazonia. Braz J Biol. 2016;76: 268-276. doi:10.1590/1519-6984.22514

42. Duncanson L, Rourke O, Dubayah R. Small Sample Sizes Yield Biased Allometric Equations in Temperate Forests. Sci Rep. 2015;5: 17153. doi:10.1038/srep17153

43. Arasa-Gisbert R, Vayreda J, Román-Cuesta RM, Gaytán SA, Mayorga R, Retana J. Forest diversity plays a key role in determining the stand carbon stocks of Mexican forests. Forest Ecology and Management. 2018;415-416. doi:10.1016/j.foreco.2018.02.023

44. Clark DB, Ferraz A, Clark DA, Kellner JR, Letcher SG, Saatchi S. Diversity, distribution and dynamics of large trees across an old-growth lowland tropical rain forest landscape. PLOS ONE. 2019;14: e0224896. doi:10.1371/journal.pone.0224896

45. Sullivan MJP, Talbot J, Lewis SL, Phillips OL, Qie L, Begne SK, et al. Diversity and carbon storage across the tropical forest biome. Sci Rep. 2017;7: 39102. doi:10.1038/srep39102 
bioRxiv preprint doi: https://doi.org/10.1101/2021.08.04.455098; this version posted August 4, 2021. The copyright holder for this preprint (which was not certified by peer review) is the author/funder, who has granted bioRxiv a license to display the preprint in perpetuity. It is made available under aCC-BY 4.0 International license.

493

494

495 